\title{
Development and Effect of Recessive Courses Resources in Higher Education Teaching
}

\author{
Yan Liu \\ School of Marxism \\ Northeast Dianli University \\ Jinlin, China
}

\begin{abstract}
By analyzing the connotation and category of recessive courses and its resources, the author reviewed its development process and theoretical foundation to discuss reasonable access to develop recessive courses resources in higher education teaching and the necessity to utilize recessive courses reasonably.
\end{abstract}

\section{Keywords -recessive courses; higher education}

\section{THE CONNOTATION AND CATEGORY OF RECESSIVE COURSES AND ITS RESOURCES}

Recessive courses were defined in Education Dictionary as follows: Informal or unconscious school learning experience that school teaching and course plan did not stipulate clearly. They are also called implicit curriculum, latent curriculum and informal curriculum. Generalized recessive courses refer to experience, value concept, thought, and the influence of the contents of the ideology and culture students gained unconsciously or curriculum appeared indirectly and implicitly in the school situation. Recessive courses doesn't appear directly for educates. Educates are educated in unconscious state with infection and influence of ideological content so they have no objection and resistance. Recessive courses resources cover all aspects of school life. In terms of the category, they are divided into three levels: implements level, system level and spirit level. Implements level of recessive courses resources include content and layout of school buildings, garden design, school teaching facilities, building layout, site and environment and so on. Campus environment is the carrier of campus culture and every entity of campus environment carries culture information, passes the education concept. The university campus is a combination of natural landscape and cultural atmosphere, it edifies and infects students living here, appealing students to come here. System level of recessive courses resources include organizations and institutes of the school, teaching management system, scientific research management system, enrollment system, students' daily management system, students' rewards and punishment system, faculty and staff performance evaluation and promotion incentive system. Spirit level of recessive courses resources include humanistic spirit and scientific spirit

This paper is phased research fruits of school educational reform project No.JX201428 "Ideological and political theory course teaching discourse system innovation research in colleges and universities" and Jilin institute of higher education teaching reform project No.JGJX2015C36 "Ideological and political education research based on the combination of explicit and implicit education in colleges and universities". such as school spirit, school motto and school song, spirits of teaching and learning, style of class and dorms, school teaching thought, teacher's ethics, interpersonal relationships. By attending extracurricular activities like campus culture activities and volunteer service activities, students will improve the ability and strengthen their will. The extracurricular recessive courses edify students silently and gradually. Development and utilization of recessive courses resources is complementation to the dominant course, to some extent it is a kind of sublimate of dominant education of college students' ideological quality and life ideal, exerts a guide in the college students' innovation ability, practical ability and entrepreneurial ability. Therefore, the effective development and utilization of recessive courses resources of college teaching is a beneficial supplement to dominant courses.

\section{REVIEW ON THE DEVELOPMENT PROCESS OF RECESSIVE COURSES}

At the beginning of the 20th century American scholar John Dewey proposed recessive courses. He said: "There is an opinion, a man of learning is only the specific things he was studying, and it is perhaps the biggest mistake of all education". [1] Dewey's idea about recessive courses has inspired his student William Heard Kilpatric. He conducted in-depth research on the basis of Dewey and exactly described what recessive courses are. He said every kind of learning is composed of three parts: primary learning, associate learning and concomitant learning. Primary learning refers to direct learning to things. Associate learning refers to the relevant learning associated with primary learning. Concomitant learning is that emotion and attitude learning associated with primary learning. Dewey's "incidental learning" and Kilpatric's "associate learning" have involved the related problems of recessive courses and they are the foundation of recessive course we study today.

In 1958, a British scientist Michael Polanyi had put forward the concept of "recessive knowledge" in his book The Research of the People for the first time and later he gave a thorough elaboration in the books Personal Knowledge, The Hidden Dimensions. He pointed out the importance of recessive knowledge in scientific research and other activities of social practice. Polanyi's proposal on recessive knowledge is considered to be the third "Copernicus revolution" on the 
human epistemology. [2] Starting from the 1960 s, scholars like Sternberg, Ikujiro Nonaka, Barton, Verna Alee and Wang Delu have further elaborated recessive knowledge. Through their understanding and definition are different, to some extent, there are a lot of in common: receive knowledge is generally difficult to express in people's mind; People acquire recessive knowledge must by the individual experience, practice and comprehension; Recessive knowledge has a lot to do with the individual experience; Recessive knowledge plays an important role in achieving individual goals; Recessive knowledge has practical application value. [3] Recessive knowledge research provides the theoretical support for the research of recessive courses and enriches the fruits of recessive courses. There are two perspectives in many research fields causing the attention of many scholars. One is a research and discussion on the recessive information of class and school life, which is first put forward by the United States educator Jackson (P.W. Jackson) in the book Life Class in 1968. Compared to the formal curriculum in the school education in a planned and organized way, the recessive courses are unexpected or unplanned knowledge, values, ideological norms and attitudes that students gained in the learning environment. Therefore, Jackson was remembered as the first educator to put forward the concept of "recessive course". The other perspective the ideology information implied in the school curriculum. American scholar Michael W. Apple thought some social groups tend to filter out the particular kind of knowledge and combine to the school curriculum, the contents influence student's thought, emotion and attitude in implicit ways, play the function of maintaining and copying the existing social system. Therefore, curriculum knowledge involves in the ideological information.

In the middle of 1980s, Chinese scholars begin to pay close attention to recessive courses research. In recent years, research on this aspect has emerged constantly. Research scope and issues are mostly about the potential impact of school's hardware and soft environment on students' development. Such as discussing the school architecture, environmental layout, ceremony, school rules and regulations, the school spirit and class discipline, campus culture, interpersonal relationship, gender differences, etc.

\section{DEVELOPMENT ACCESSES TO RECESSIVE COURSES IN HIGHER EDUCATION}

Development of recessive courses resources should start from the following three aspects. First, improving and completing the recessive courses on implements level. The style of university is formed in the accumulation of years of change. Ancient architectures carrying a long history, elegant and quiet garden design, complete facilities of sports venues, the building of the college students' activity center filled with academic atmosphere, silent sales counter in campus, all of the material environment of campus inadvertently affect students and teachers' emotion because beautiful campus environment beautifies the students' mind, guides the students to grow and thrive. College students come here with a goal and get out of school with their social ideal. Second, improving and innovating school system. School buildings and regulations are used to cultivate more excellent talents for the society, to provide elites keeping pace with times so the campus system needs to be innovated timely. The students can feel the existence and constraint of the school rules in the process of learning life every moment and the rigorous, pragmatic and innovative system is like an "invisible hand" in the campus life guiding the students obeying rules. "The teaching aim of recessive courses can keep persistent because its knowledge is that student experience every day then learn firmly". [4] The effects of the school system will gradually impress students and become the quality of life. Third, enhance the university spirit culture. University spirit is spiritual civilization achievements with unique temperament formed in its own existence and development. It is scientific spirit symbol and concrete cohesion of the age as well as the advanced form of the whole human society civilization. As the prestigious philosopher Polanyi said, "What we know is more than what we can tell". University spirit is the carrier of recessive courses. It decides what kind of students the university cultivates. University spirit is expressed through its school motto and school spirit while president and teachers at the university are the image spokesperson of the school. Teachers' values (world outlook, the outlook on life and values), characters and attitude have affected students subtly. "The spirit is full of permeability and the permeability is essentially thought to be the influence of method, moral consciousness, value idea and the way of behavior. It forms by a certain atmosphere and promotes mutual influence among people. What is more important is the leading effect of university teacher's academic thoughts, academic methods, learning attitude, rigorous style of work and exemplary deeds that exposed to the students. This effect is subtle and nuanced and its effect is also potential and lasting".

\section{EFFECT OF RECESSIVE COURSES IN HIGHER TEACHING}

Recessive education is purposeful and conscious to educators while unconscious to educatees. Education should combine affection to science because recessive education exerts important influence on people's emotion and consciousness. Effectiveness of recessive courses resources in the education teaching in colleges and universities is mainly manifested in the following respects. First of all, taking the advantages of the recessive courses resources and complementing and improving the shortage of the dominant curriculum. Dominant curriculum is targeted and planned official teaching activities while recessive courses are hidden and potential. Development and utilization of recessive courses resources can be complementary with dominant course. Combing the recessive education to dominant education and using the two to crack problems in current education teaching so as to improve the effectiveness of the higher education. Second, recessive courses have the function of permeability and implication. They effectively avoid resistance and disgust in the way that influences students subtly and caters to students' thoughts and in accordance with the law of youth education thereby improve the effectiveness of the education teaching and achieve the goal of enlightenment education. Third, the recessive courses have the educational function of improving ability and educating beauty, they reflect the concept of man's all-round development education. Recessive courses can inspire students' initiative goal behaviors, thus 
effectively stimulate students' inner potential, promote the allround development of students, which embodies the "students first" education philosophy.

Finally, the recessive courses resources have two sides. There is the distinction between positive and negative sides. Analyzing from the cloth, words, outlooks of life and value, we can find that some recessive courses resources express positive information while others express negative information. The negative effect of recessive courses resources has negative impact on educatees. Therefore, educators should develop and use the resources reasonably to make them play positive effect in higher teaching.

\section{REFERENCES}

[1] [US] John. Dewey. Translated by Jiang Wenmin. How we thought experience and education[M]. Beijing: People's Education Press, 1991.

[2] Yang Wenjiao. Theory and practice of recessive knowledge. Ocean university of China publishing house. Mar, 2014, Page 1.

[3] Yang Wenjiao. Theory and practice of recessive knowledge. Ocean university of China publishing house, Mar, 2014, Page 14

[4] Wu Gang. The forefront of sociology of education issues. Shanghai: Shanghai Educational Publishing House. 2011. Page 80

[5] Guo Meini. The realization of the recessive ideological and political education method of contemporary college students. University Eduaction. 2013, Page 48. 